NBER WORKING PAPER SERIES

\author{
CAPITAL FLOWS, CONSUMPTION BOOMS AND ASSET BUBBLES: \\ A BEHAVIOURAL ALTERNATIVE TO THE SAVINGS GLUT HYPOTHESIS
}

\author{
David Laibson \\ Johanna Mollerstrom \\ Working Paper 15759 \\ http://www.nber.org/papers/w15759
NATIONAL BUREAU OF ECONOMIC RESEARCH
1050 Massachusetts Avenue
Cambridge, MA 02138
February 2010

This paper was developed from the Frank Hahn Lecture, delivered at the Royal Economic Society Meeting in spring 2009. We acknowledge terrific research support from Kyle Chauvin. We are grateful for the advice of Effi Benmelech, Alan Blinder, Emmanuel Farhi, Benjamin Friedman, Edward Glaeser, Owen Lamont, Jaewoo Lee, Andrei Shleifer, Jeremy Stein, Luis Viceira and participants at the Royal Economic Society Meeting in 2009. Laibson acknowledges financial support from the National Science Foundation (DMS-0527518) and the National Institute on Aging (R01-AG-021650, R01-AG-1665, P30-AG-012810). The views expressed herein are those of the authors and do not necessarily reflect the views of the National Bureau of Economic Research.

NBER working papers are circulated for discussion and comment purposes. They have not been peerreviewed or been subject to the review by the NBER Board of Directors that accompanies official NBER publications.

(C) 2010 by David Laibson and Johanna Mollerstrom. All rights reserved. Short sections of text, not to exceed two paragraphs, may be quoted without explicit permission provided that full credit, including (C) notice, is given to the source. 
Capital Flows, Consumption Booms and Asset Bubbles: A Behavioural Alternative to the Savings Glut Hypothesis

David Laibson and Johanna Mollerstrom

NBER Working Paper No. 15759

February 2010

JEL No. E02,F01,G01

\begin{abstract}
Bernanke (2005) hypothesized that a "global savings glut" was causing large trade imbalances. However, we show that the global savings rates did not show a robust upward trend during the relevant period. Moreover, if there had been a global savings glut there should have been a large investment boom in the countries that imported capital. Instead, those countries experienced consumption booms. National asset bubbles explain the international imbalances. The bubbles raised consumption, resulting in large trade deficits. In a sample of 18 OECD countries plus China, movements in home prices alone explain half of the variation in trade deficits.
\end{abstract}

\author{
David Laibson \\ Department of Economics \\ Littauer M-12 \\ Harvard University \\ Cambridge, MA 02138 \\ and NBER \\ dlaibson@harvard.edu \\ Johanna Mollerstrom \\ Department of Economics \\ Littauer Center \\ Harvard University \\ Cambridge, MA 02138 \\ jmollers@fas.harvard.edu
}




\section{Facts and Figures}

Over the last decade, extreme asset price increases have coincided with unprecedented imbalances in international financial flows. Many developed countries have run enormous trade deficits, while many developing countries have run large surpluses. In 1996, the US trade deficit was $1.5 \%$ of GDP, but by 2006 the trade deficit had ballooned to $6.0 \%$. Conversely, over this period, the Chinese trade surplus rose significantly. Figure 1 plots the current account surplus in the United States, China, OECD and the BRIC countries. ${ }^{1}$

Figure 1 about here.

Economists have tried to identify the mechanisms that are causing these international imbalances and the coincident asset price movements (e.g., Ventura 2001; Kraay and Ventura 2007; Caballero, Farhi, and Gourinchas 2008a,b; Basco 2009). One leading explanation has been the existence of a "global savings glut", which Ben Bernanke identified in two influential speeches in 2005 (Bernanke, 2005). According to this account, in the aftermath of the Asian financial crisis of 1997-1998, developing countries increased their supply of savings. ${ }^{2}$ This shift is thought to have caused developing countries to run large current account surpluses and developed countries to run offsetting current account deficits.

In the current paper, we argue that the theory of a global savings glut does not explain the observed data. To make this point, we provide several arguments. First, we show that the global savings and investment rates did not show a robust upward trend during the period that Bernanke associated with the global savings glut, 1996-2006. ${ }^{3}$ Had a global savings glut existed (an outward shift in the world supply of savings) it should have caused a boom in global observed savings and investment.

Second, we calibrate a model for the economies that received capital inflows. The calibrated model predicts that if there had been a savings

\footnotetext{
${ }^{1}$ The BRIC countries are Brazil, Russia, India, and China.

${ }^{2}$ The Asian financial crisis was a series of crises starting in July 1997. The crisis started in Thailand with the collapse of the Thai baht. The crisis then spread from Thailand to most of Southeast Asia, particularly Indonesia and South Korea. In some Asian countries the excess savings (i.e. savings in excess of investment) arose because of a decrease in investment rather than a rise in savings.

${ }^{3}$ We start with 1996, since this just predates the Asian financial crises. We end with 2006, since this is the year that the U.S. current account deficit peaked.
} 
glut there should have been a large investment boom in the countries that imported capital. For our benchmark calibration, we find that the investment rate should have risen by at least $4 \%$ of GDP. Intuitively, if the Chinese government exogenously loaned U.S. households a trillion dollars, those U.S. households should have chosen to invest a substantial share of those funds to help make the interest payments. However, such an investment boom did not occur. Instead the US absorbed most of the imported capital through a consumption boom.

This calibration also casts a critical light on the arguments of Caballero, Farhi, and Gourinchas (2008a, b), hereafter CFG. Like Bernanke, CFG also hypothesise that an external shock led the U.S. to run international imbalances. Unlike Bernanke, they argue that this flow derived from an assetshortage in Asia. In their account, Asian savers sought new markets in which to invest their wealth. However, the exogenous capital flow hypothesised by CFG should have led to a counter-factual investment boom in the economies that absorbed those flows.

We suggest an alternative explanation for the unbalanced financial flows of the past decade. We argue that asset price movements, including the bubbles in equity markets and residential real estate markets, do a better job of explaining the international financial flows. ${ }^{4}$ During the period of inflated asset values, U.S. consumers spent their new wealth, with a marginal propensity to consume of about $4 \%$. Our calibrated model predicts the consumption patterns that occurred in the developed economies, specifically the selective consumption booms that arose in the countries that experienced asset bubbles. Our calibrated model also explains why the capital imports were consumed and not invested. Our approach provides a simple and parsimonious explanation to the puzzle of large international imbalances. The asset bubble framework quantitatively explains the large current account deficit of the US (peaking at 6\%) and the modest increase in investment during the same period (less than $2 \%$ of GDP). ${ }^{5}$

Finally, we show empirically that asset price movements explain a substantial share of the cross-sectional variation in international financial flows. In a sample of 18 OECD countries plus China, we find that movements in residential home prices alone explain around $50 \%$ of the variation in accumulated current account deficits. Figure 2 plots the percentage increase in the price of residential real estate on the horizontal axis and the accumulated

\footnotetext{
${ }^{4}$ In our model we assume the existence of a bubble, both in housing and equity, which is not uncontroversial. In doing so, we are building on the growing literature that claims that such bubbles do exist. See e.g. Schiller (2005) and Glaeser et al. (2008).

${ }^{5}$ Investment is compared to the average level from 1929-2008.
} 
current account balance on the vertical axis. ${ }^{6}$

Figure 2 about here

In the last section of the paper, we emphasise two open questions. First, our model does not explain why the asset price bubbles occurred in the first place. Second, our model does not explain why interest rates fell between 2000 and 2003. We argue that the fall in real interest rates can probably be traced to five factors: (1) a shift from equities to fixed income instruments during and after the bursting of the tech bubble, also accompanied by an enormous increase in fixed-income foreign reserves (e.g., Chinese investments in Treasuries); (2) expansionary monetary policy during and after the 2001 recession; (3) the asset shift from Asia to the developed world studied by CFG (2008a and 2008b); (4) a misperception that the world economy had become less risky ("the great moderation"); and (5) misperceptions about the riskiness of non-governmental debt, due partially to the expansion of structured finance and the blessings of the rating agencies. Finally, we emphasise that a global savings glut probably does not explain the fall in interest rates, since the period of falling interest rates coincided with a falling global savings rate.

The paper is organised as follows. In Section II we describe the key arguments - both empirical and theoretical - that contradict the theory of a global savings glut. In Section III we discuss our alternative theory: asset bubbles evoked a consumption boom in many developed countries, leading to large current account deficits. In Section IV we conclude and discuss open questions.

\section{What's wrong with the hypothesis of a global savings glut?}

In this section, we begin by describing movements in the global investment rate, I/Y, and the global savings rate, $\mathrm{S} / \mathrm{Y}$. Then, we solve and calibrate a model of an economy that receives an exogenous capital inflow that is equal to the current account deficits that the U.S. ran from 1996-2006 (the period that Bernanke was discussing in his speeches on the global savings glut). We show that most of this inflow should have been absorbed as investment. In contrast to this prediction, the U.S. investment rate fluctuated over this period and ended only marginally higher than it started.

\footnotetext{
${ }^{6}$ See Aizenman and Jinjarak (2008) for a much more detailed analysis of this relationship.
} 


\subsection{Investment and savings during the "global savings glut"}

Figure 3 plots the U.S. current account deficit from 1929-2008 (the period covered in the NIPA accounts). ${ }^{7}$ The current period of large global imbalances began in the latter half of the 1990's. Over the 80-year sample plotted in Figure 3, the current account deficits peak in 2006, at $6.0 \%$ of GDP. The next largest peak was about half as large: $3.3 \%$ in 1987.

Figure 3 about here

The recent extraordinary international imbalances have not been mirrored by extraordinary investment flows. While the U.S. ran enormous current account deficits, the U.S. investment rate was little changed. Figure 4 plots the investment rate - gross private domestic investment divided by GDP - from 1929-2008. The investment rate was $15.8 \%$ of GDP in 1996, when the current account deficit was $1.5 \%$ of GDP. The investment rate fluctuated from 1997 to 2006, falling to a low of $15.4 \%$ in 2002 and then gently rising, ending in 2006, 1.6 percentage points higher than it started. Specifically, just two years before Bernanke stated the savings glut hypothesis in 2005, the investment rate was $15.5 \%$, which is below the level in 1996. By contrast, the current account deficit rose nearly monotonically over the 1996-2006 period, peaking in 20064.5 percentage points above its starting level. ${ }^{8}$

Figure 4 about here

This relatively stable investment rate may seem surprising in the midst of the U.S. housing bubble. However, the housing bubble had only a modest impact on total U.S. investment. Figure 5 outlines residential investment as percentage of GDP for the US. In 1996, residential investment was $4.3 \%$ of GDP while in 2006 the corresponding figure was 5.7\%. In 2005 residential investment peaked at $6.1 \%$ of GDP.

Figure 5 about here

The global investment rate also changed little over this period. According to the IMF World Economic Outlook, the global investment rate was

\footnotetext{
${ }^{7}$ The U.S. National Income and Product Accounts (NIPA) are compiled by the U.S. Bureau of Economic Analysis.

${ }^{8}$ Some authors claim that the NIPA account understates the true investment in the US. This could change the conclusion that there was no investment boom. See e.g. Hausman and Sturzenegger (2005) and McGrattan and Prescott (2009).
} 
$22.4 \%$ in 1996. Over the period 1996-2006, the global investment rate first fell slightly and then rose slightly. Its trough value was $20.9 \%$ in 2002 . In 2006, the global saving rate was $23.2 \%$. Figure 6 plots the global investment rate and the global savings rate.

Figure 6 about here

In principle, the global savings rate should match the global investment rate. However, accounting problems create a small gap. In 1996 the global savings rate was $22.3 \%$. After this point, the global savings rate first fell and then rose. Its trough value was $20.6 \%$. In 2002 its value was $23.9 \%$. In 2007 and 2008, the global savings rate continued to rise, partly as a result of the financial crisis.

Modest changes in investment and savings rates are hard to reconcile with a large outward shift in the supply of saving. However, such an outcome is not impossible. For example, if the demand for saving were perfectly inelastic, then the supply of saving could shift out without having any effect on the equilibrium level of saving and investment.

However, a vertical demand curve for capital is inconsistent with a calibrated Cobb-Douglas production function. To quantitatively study the magnitude of the effects that we should have observed, we next solve a partial equilibrium model of an economy that receives a large capital inflow.

\section{Investment and capital in a partial equilibrium economy}

In this section we solve for equilibrium in a Cobb-Douglas economy that receives an exogenous capital inflow calibrated to match the U.S. current account deficit from 1997 to 2006 . We use this model to characterise the effect of an exogenous capital inflow on a developed economy like the U.S. ${ }^{9}$

\subsection{The household's optimisation problem}

The economy is in competitive equilibrium, so individual agents treat prices (including wages) as given. A representative agent maximises lifetime utility,

$$
\sum_{t=0}^{\infty} \beta^{t} u\left(C_{t}\right),
$$

\footnotetext{
${ }^{9}$ The U.S. National Income and Product Accounts (NIPA) are compiled by the U.S. Bureau of Economic Analysis.
} 
where $\beta$ is the (exponential) discount factor and $u$ is the felicity function. We assume constant relative risk aversion, $\gamma, \mathrm{so}^{7}$

$$
u(C)=\frac{C^{1-\gamma}}{1-\gamma} .
$$

We adopt the following notational and timing assumptions.

1. Period $t$ begins, with holdings of domestic capital $K_{t}$ and foreign debt $D_{t}$ (a positive value of foreign debt represents a liability).

2. Factor payments $R_{t} K_{t}, R_{t} D_{t}$ and $Y_{t}^{L}$ are made, where $R_{t}$ is the gross interest rate (which incorporates depreciation), $r=R-1$ is the net interest rate, and $Y_{t}^{L}$ is labor income. We assume that labor supply is exogenous, so $Y_{t}^{L}$ is exogenous from the perspective of the household.

3. The agent chooses consumption, $C_{t}$, subject to a dynamic budget constraint

$$
K_{t+1}-D_{t+1}=R_{t} K_{t}+Y_{t}^{L}-R_{t} D_{t}-C_{t}
$$

4. Period $t$ ends and period $t+1$ begins.

Note that step 3 is underidentified, since the agent can accumulate wealth either by acquiring capital, $K$, or paying off her foreign debt, $D$. Conversely, the agent can decumulate wealth either by reducing capital, $K$, or acquiring foreign debt, $D$. This indeterminancy is resolved by exogenously fixing the time-path of $D$. Hence, the endogenous margin from the perspective of the domestic household is adjustment in $K$. We are interested in studying the case of an exogenous timepath for $D$, since this reproduces the savings glut hypothesis (from the perspective of the developed economies that are importing capital from Asia).

The problem of the representative agent can be expressed recursively:

$$
V_{t}\left(K_{t}, D_{t}\right)=u\left(C_{t}\right)+\beta V_{t+1}\left(K_{t+1}, D_{t+1}\right),
$$

where $V_{t}$ is a (time-dependent) value function. The dependence of $V_{t}$ on equilibrium prices, like wages and interest rates, is suppressed among the state variables, since wages and interest are exogenous from the perspective

\footnotetext{
${ }^{7}$ We omit the standard constant term, $\frac{-1}{1-\gamma}$ to simplify exposition (thereby eliminating a constant term in our value function). This omission is without loss of generality, since the limit policies as $\gamma \rightarrow 1$ are unaffected by the omission (even though $\lim _{\gamma \rightarrow 1} u(c)$ is not well-defined).
} 
of the agent. These time-varying (individually exogenous) effects are captured by the time-varying structure of $V_{t}$. These dependencies will be made explicit below.

We will guess and verify the following solution for the Bellman Equation of the individual agent.

$$
\begin{aligned}
V_{t}\left(K_{t}, D_{t}\right) & =\frac{\psi_{t}\left(R_{t} K_{t}+Y_{t}^{L}-R_{t} D_{t}+H_{t}\right)^{1-\gamma}}{1-\gamma} \\
H_{t} & =\sum_{n=1}^{\infty} \frac{Y_{t+n}^{L}}{\prod_{s=1}^{n} R_{t+s}}
\end{aligned}
$$

Note that $\psi_{t}$ is a time-dependent parameter to be solved. The discounted value of future labor income is represented by $H_{t}$, which also has a recursive representation:

$$
H_{t}=\frac{Y_{t+1}+H_{t+1}}{R_{t+1}} .
$$

The envelope theorem implies:

$$
C_{t}=\psi_{t}^{-\frac{1}{\gamma}}\left(R_{t} K_{t}+Y_{t}^{L}-R_{t} D_{t}+H_{t}\right) .
$$

Substituting back into the Bellman Equation (1), yields,

$$
\begin{aligned}
\frac{\psi_{t}\left(R_{t} K_{t}+Y_{t}^{L}-R_{t} D_{t}+H_{t}\right)^{1-\gamma}}{1-\gamma}= \\
\quad \frac{C_{t}^{1-\gamma}}{1-\gamma}+\beta \frac{\psi_{t+1}\left(R_{t+1} K_{t+1}+Y_{t+1}^{L}-R_{t+1} D_{t+1}+H_{t+1}\right)^{1-\gamma}}{1-\gamma} .
\end{aligned}
$$

Substituting for $C_{t}$ (Eq. 4) and dividing by $\left(R_{t} K_{t}+Y_{t}^{L}-R_{t} D_{t}+H_{t}\right)^{1-\gamma}$ yields,

$$
1=\psi_{t}^{-\frac{1}{\gamma}}+\beta\left[\frac{\psi_{t+1}}{\psi_{t}} \frac{\left(R_{t+1} K_{t+1}+Y_{t+1}^{L}-R_{t+1} D_{t+1}+H_{t+1}\right)^{1-\gamma}}{\left(R_{t} K_{t}+Y_{t}^{L}-R_{t} D_{t}+H_{t}\right)^{1-\gamma}}\right] .
$$

This can be further simplified by several more subsitutions. Eventually, the following recursive expression is obtained:

$$
\psi_{t}^{\frac{1}{\gamma}}=1+\beta^{\frac{1}{\gamma}} R_{t+1}^{\frac{1}{\gamma}-1} \psi_{t+1}^{\frac{1}{\gamma}} .
$$

The following algorithm characterises the optimal consumption path. Start with $\left\{W_{0}, D_{0}\right\}$, the equilibrium sequence of interest rates $\left\{R_{t}\right\}_{t=0}^{\infty}$, 
and the equilibrium sequence of labor income $\left\{Y_{t}^{L}\right\}_{t=0}^{\infty}$. Let $H_{t}$ be given by equation (3) for all $t$. Let,

$$
\psi_{t}^{\frac{1}{\gamma}}=1+\sum_{n=1}^{\infty} \beta^{\frac{n}{\gamma}} \prod_{s=1}^{n} R_{t+s}^{\frac{1}{\gamma}-1},
$$

for all $t$. Equation (6) is the solution to equation (5). Then iterate the following equations forward in time to solve for the optimal consumption path.

$$
\begin{aligned}
C_{t} & =\psi_{t}^{-\frac{1}{\gamma}}\left(R_{t} K_{t}+Y_{t}^{L}-R_{t} D_{t}+H_{t}\right) \\
K_{t+1}-D_{t+1} & =R_{t} K_{t}+Y_{t}^{L}-R_{t} D_{t}-C_{t} .
\end{aligned}
$$

These equations are the consumption function and the dynamic budget constraint for financial wealth respectively.

\subsection{The aggregate economy}

The aggregate economy is characterised by a Cobb-Douglas production function (with labor supply, $L$, normalised to unity), so the production function is,

$$
F(K, L)=K^{\alpha} L^{1-\alpha}=K^{\alpha},
$$

where $K$ is the capital stock and $0<\alpha<1$.

The marginal product of capital, net of capital depreciation, $\delta$, is

$$
F_{K}(K, L)=r=R-1=\alpha K^{\alpha-1}-\delta .
$$

The marginal product of labor is

$$
F_{L}(K, L)=Y^{L}=(1-\alpha) K^{\alpha}
$$

The aggregate dynamic budget constraint is given by

$$
K_{t+1}-D_{t+1}=K_{t}^{\alpha}+(1-\delta) K_{t}-R_{t} D_{t}-C_{t},
$$

where $D$ is the net foreign debt position.

We now review some basic national accounting identities. The current account deficit in period $t$ is $\Delta D_{t+1}=D_{t+1}-D_{t}$. The net foreign debt position and the trade balance are related by the identity

$$
\Delta D_{t+1}=r_{t} D_{t}-N X_{t} .
$$


Gross domestic product can be decomposed into

$$
\begin{aligned}
K_{t}^{\alpha} & =C_{t}+I_{t}+N X_{t} \\
& =C_{t}+I_{t}-D_{t+1}+R_{t} D_{t},
\end{aligned}
$$

where $I_{t}$ is gross domestic investment,

$$
I_{t}=\Delta K_{t+1}+\delta K_{t}=K_{t}^{\alpha}-C_{t}+D_{t+1}-R_{t} D_{t} .
$$

So the rate of gross domestic investment is

$$
\frac{I_{t}}{G D P_{t}}=\frac{\Delta K_{t+1}+\delta K_{t}}{K_{t}^{\alpha}} .
$$

Likewise, the rate of national savings is

$$
\frac{S_{t}}{G D P_{t}}=\frac{K_{t}^{\alpha}-C_{t}}{K_{t}^{\alpha}}
$$

Note that these expressions are related through the trade balance.

$$
S_{t}=I_{t}+N X_{t}
$$

\subsection{Competitive Equilibrium}

Definition: An allocation is a competitive equilbrium iff the following conditions hold for all $t$.

(i) Individual optimisation and dynamic budget constraints:

$$
\begin{aligned}
C_{t} & =\psi_{t}^{-\frac{1}{\gamma}}\left(R_{t} K_{t}+Y_{t}^{L}-R_{t} D_{t}+H_{t}\right) \\
\psi_{t}^{\frac{1}{\gamma}} & =1+\sum_{n=1}^{\infty} \beta^{\frac{n}{\gamma}} \prod_{s=1}^{n} R_{t+s}^{\frac{1}{\gamma}-1} \\
K_{t+1}-D_{t+1} & =R_{t} K_{t}+Y_{t}^{L}-R_{t} D_{t}-C_{t} \\
H_{t} & =\sum_{n=1}^{\infty} \frac{(1-\alpha) K_{t+n}^{\alpha}}{\prod_{s=1}^{n} R_{t+s}}
\end{aligned}
$$

(ii) Competitive factor pricing:

$$
\begin{aligned}
R_{t} & =\alpha K_{t}^{\alpha-1}+(1-\delta) \\
Y_{t}^{L} & =(1-\alpha) K_{t}^{\alpha}
\end{aligned}
$$


(iii) Boundary condition at infinity:

$$
\lim _{t \rightarrow \infty} R_{t}=\beta^{-1}
$$

The competitive equilibrium can be characterised by computationally solving the model forward, perturbing the initial conditions, $H_{t}$ and $\psi_{t}$, until the boundary condition is satisfied.

Finally, we can characterise the steady state:

$$
\begin{aligned}
R \beta & =1 \\
R-1 & =\alpha K^{\alpha-1}-\delta \\
C & =\left(1-\frac{1}{R}\right)\left[K^{\alpha}+(1-\delta) K-R D+\frac{(1-\alpha) K^{\alpha}}{R-1}\right] .
\end{aligned}
$$

The first equation is derived from the Euler Equation - consumption is constant when $R \beta=1$. The second equation equates the interest rate with the marginal product of capital. The third equation is the consumption function evaluated with the steady state marginal propensity to consume, $\left(1-\frac{1}{R}\right)$, and the steady state level of total wealth. The second and third restrictions jointly imply that the dynamic budget constraint is satisfied. ${ }^{8}$

\subsection{Simulations}

To calibrate our simulations, we set $\alpha=0.33, \beta=0.97, \delta=0.04$, and $\gamma \in\{1,2, \ldots, 5\}$. Recall that the time-path of $D$ is fixed in our model, since we are studying the effects of an exogenous flow of foreign capital that matches the observed flow from 1996 to 2006 . We therefore choose the sequence of net foreign debt positions, $D_{t}$, that reproduces the pattern of observed

$$
\begin{aligned}
C & =\left(1-\frac{1}{R}\right)\left[K^{\alpha}+(1-\delta) K-R D+\frac{(1-\alpha) K^{\alpha}}{R-1}\right] \\
& =K^{\alpha}+\left(\frac{R-1}{R}\right)(1-\delta) K-r D-\frac{\alpha K^{\alpha}}{R} \\
& =K^{\alpha}+K\left[\left(\frac{R-1}{R}\right)(1-\delta)-\frac{\alpha K^{\alpha-1}}{R}\right]-r D \\
& =K^{\alpha}-\delta K-r D
\end{aligned}
$$


current account deficits from 1996 to 2006. To identify the hypothetical effect of a savings glut, we study the excess current account deficit, which is defined as the current account deficit in year $t$ minus the current account deficit that existed before the savings glut (i.e. the 1996 current account deficit). We choose the sequence of $D_{t}$ values so that the calibrated current account deficits (as a percent of GDP) match the empirical excess current account deficits (as a percent of GDP).

Figure 7 reports our simulated results, from 1996 to 2006 for the five different values of $\gamma$. The predicted pattern of investment (relative to the 1996 baseline) does not match the observed pattern of investment. Two problems are apparent. First, simulated investment rises almost monotonically, while empirical investment fluctuates, even falling below its starting point in the middle of the savings glut period. Second, the simulated increase in investment is much larger than the empirical increase in investment.

Figure 7 about here.

This analysis quantitatively confirms the intuition that we reviewed before. An exogenous inflow of capital should have led to an investment boom in the U.S. (so U.S. households would be in a good position to repay their new debts), but no investment boom occurrred.

\section{Bubble-based model of global imbalances}

We now turn to an alternative explanation for global imbalances. This alternative is simple: a select group of countries experienced asset bubbles, causing consumption booms and trade deficits in those countries. Conversely, their trading partners experienced trade surpluses.

\subsection{The Model}

We adopt the same notation as before, but we now make three simplifying assumptions to improve tractability. First, we use continuous time. This is purely for analytic convenience and has no impact on our quantitative results. Many of our expressions are more compact in continuous time. Second, we study a small open economy that faces fixed world factor prices. Third, we study the steady state case in which the discount rate equals the interest rate. These three assumptions enable us to express our results as simple closed form expressions. Generalising the second and third assump- 
tions does very little to change the quantitative implications of the bubble analysis that follows.

The representative household maximises an exponentially weighted integral of utility flows:

$$
\int_{0}^{\infty} \exp (-\rho t) u\left(C_{t}\right) d t
$$

subject to

$$
d K=Y^{L}-C+r(K-D)+d D .
$$

Here $\rho$ is the exponential discount rate, $K$ is domestic capital, $Y^{L}$ is labor income, $C$ is consumption, $r$ is the interest rate, and $D$ equals foreign debt. As we already stated, we assume that $r=\rho$ (a steady state restriction). Again, we assume $\gamma$ is the coefficient of constant relative risk aversion.

We assume that a bubble begins an instant after date $t_{B}$ and ends at date $t_{B}+N$. In other words, the bubble exists when $t \in\left(t_{B}, t_{B}+N\right]$. We assume that the asset bubble immediately raises the notional value of fixed capital by an increment $\zeta K$. We think of this as the (discounted) value of productivity gains that are anticipated to occur at some date in the future (say $N$ periods away). ${ }^{9}$ In the setting that we are studying, the marginal propensity to consume out of wealth is $r$, so that the $\zeta K$ increase in notional wealth leads consumption to rise by $r \zeta K$.

Since, $r=\rho$, pre-bubble consumption is equal to the annuity value of wealth:

$$
C=Y^{L}+r(K-D) .
$$

Bubble consumption is the annuity value of bubble-inclusive wealth:

$$
C^{\prime}=Y^{L}+r(K-D)+r \zeta K .
$$

Recall that assets appreciate at rate $r$, so throughout the bubble period households hold wealth with notional value $\zeta K+K-D$. Capital gains and dividends are exactly offset by consumption.

\footnotetext{
${ }^{9}$ These productivity gains need to be anticipated to occur in the future, to enable the bubble to persist in the meantime. The bubble bursts once the anticipated gains are not realized. In this way our model touches upon that of Beaudry and Portier (2007) where news about the future changes expectations in a way that impacts consumption, investment and growth. Even more relevant is Christiano et al (2007), which investigages what happens when such expectations turn out to be wrong.
} 
During the bubble period, households have a shortfall in income from domestic assets of $r \zeta K$, which is borrowed from abroad. ${ }^{10}$ The resulting change to the trade deficit (which is the same as the change to the current account deficit) is

$$
r \zeta K \text {. }
$$

The trade deficit continues at this level throughout the bubble period. By contrast, the current account deficit grows, since the foreign debt is growing. Households must also pay interest on the accumulating shortfalls. Integrating these flows, yields the net accumulation of foreign debt during any sub-period, $\left(t_{B}, t_{B}+\tau\right]$, of the bubble period (where $\left.\tau<N\right)$.

$$
\begin{aligned}
D_{t_{B}+\tau}-D_{t_{B}} & =\int_{0}^{\tau} r \zeta K \exp (r[\tau-s]) d s \\
& =[\exp (r \tau)-1] \zeta K .
\end{aligned}
$$

So the (change in the) current account deficit from date 0 , an instant before the bubble starts, to date $\tau<N$, is

$$
\left|C A_{t_{B}+\tau}-C A_{t_{B}}\right|=r \zeta K+r[\exp (r \tau)-1] \zeta K .
$$

Just before the bubble bursts, at time $t_{B}+N$, assets can be decomposed into domestic assets valued at

$$
\zeta K \exp (r N)+K
$$

and debt to foreign agents valued at

$$
D+[\exp (r N)-1] \zeta K
$$

Note that the difference of these two terms is

$$
\zeta K+K-D .
$$

When the bubble bursts, the household is left with net assets:

$$
K-D-[\exp (r N)-1] \zeta K \text {. }
$$

\footnotetext{
${ }^{10}$ We assume that households borrow from foreign agents rather than selling the foreign agents over-valued domestic assets. The domestic agents have no reason to sell the domestic assets since they don't recognize that they are overvalued. Moreover, if the overvalued assets have value that is best-realized by local owners (e.g., residential real estate), then there are good reasons to expect that the foreign agents will primarily acquire fixed income claims.
} 
So consumption falls from

$$
Y^{L}+r(K-D)+r \zeta K
$$

to

$$
Y^{L}+r(K-D)-r[\exp (r N)-1] \zeta K .
$$

In other words, consumption falls by

$$
r \zeta K \exp (r N) .
$$

We can decompose this into two effects:

$$
\underbrace{r \zeta K}_{\text {Direct bubble effect }} \times \underbrace{\exp (r N)}_{\text {Accumulated debt effect }}
$$

The direct bubble effect is the reversal in the initial consumption boom. The accumulated debt effect is the consequence of accumulating debt at interest rate $r$ over an interval of length $N$. As the duration of the bubble goes to zero, the accumulated debt effect vanishes, since $\lim _{N \rightarrow 0} \exp (r N)=1$. As the duration of the bubble increases, the accumulated debt effect grows exponentially.

\subsubsection{Calibration of the bubble model}

To calibrate the bubble-model, we set $r=0.03$ and $\beta=0.97$, since, in steady state, $R \beta=1$. In steady state, the marginal propensity to consume is equal to $r$. Most empirical analysis estimates a 0.03 to 0.05 marginal propensity to consume (out of asset wealth). We will also consider MPC's over this range.

We also need to calibrate the bubble-component of the value of assets owned by U.S. households. Figure 8 plots the U.S. ratio of household wealth to GDP. ${ }^{11}$ This series fluctuated historically in a range, roughly between 3 and 3.5 units of GDP. Starting in the mid-1990's, however, the series broke from this historical range and rose sharply. At its peak in the second quarter of 2007, the series reached a value of 4.68 units of GDP. By the first quarter of 2009, the series had fallen back to upper bound of its old range. These comparisons imply an estimated bubble value of 1.2 units of GDP ( $\$ 17$ trillion). ${ }^{12}$

\footnotetext{
${ }^{11}$ The numerator is compiled by the Federal Reserve and is available back to 1952 .

${ }^{12}$ The 2007 ratio of household wealth to GDP misses part of the value of the bubble in 2007 , since it nets out the value of debt accumulated to finance consumption during the preceding bubble years (from 1996 to 2007). The key contributor is mortgage debt, which increased from 0.44 units of GDP in 1996:1 to 0.75 units of GDP in 2007:2. This analysis implies an additional bubble increment of 0.3 units of GDP.
} 
Hence, bubble-driven consumption should have amounted to $r \times 1.2$ units of GDP, or 3.6 percent of GDP. With an MPC of 0.04, the magnitude of excess (bubble-driven) consumption rises to 4.8 percent of GDP. With an MPC of 0.05, the magnitude rises to 6 percent of GDP.

These predictions of excess-consumption levels compare well to the excess trade deficits that the U.S. ran during the height of the bubble period. In 1996, before the advent of high asset prices, the trade deficit was 1.5 percent of GDP. The peak trade deficit (2006) reached 6.0 percent of GDP, or a difference of 4.5 percentage points of GDP in comparison to the 1996 level.

This preliminary analysis suggests that bubble-driven consumption might explain the level of U.S. trade imbalances. However, the analysis is incomplete, because we do not have a precise theory of the lags that relate current consumption to lagged movements in asset prices. Habit-based preferences, adjustment costs (it takes time to sell one home and buy another), and informational lags all create a subtle lagged relationship between wealth movements and consumption responses. We have only begun to think about these important and complex issues.

\subsection{Empirical relationship between price appreciation of res- idential real estate and current account deficits}

The model described above implies that countries that experience an asset bubble should also experience a consumption boom and a commensurate current account deficit. Figure 2 depicts the cross-sectional relationship between (country-level) price appreciation of housing and the current account deficit. ${ }^{12}$ Figure 9 depicts the same relationship for the trade deficit. Our analysis includes China plus all of the 18 countries for which the OECD reports price index data on residential real estate (the alphabetised list is in Table 1). We were not able to find additional countries with price data that was of high quality. We continue to take 1996 as the starting point. The end points vary by country, since they are chosen to match the peak year of the price of residential real estate. ${ }^{12}$ This bracketing approach captures

\footnotetext{
${ }^{12}$ For Norway, the balance of trade and the current account are dominated by petroleum exports. Moreover, oil prices were highly volatile during this period that we started. To address this issue, for Norway we use data on the balance of trade excluding oil. This is a special series produced by Statistics Norway. Since there is no data reported on Norway's current account balance exclusive of oil, and since Norway's unadjusted balance of trade and unadjusted current account are extremely close in magnitude, we use the balance of trade, exclusive of oil, in both the current account and the balance of trade analyses.

${ }^{12}$ If there were more than one peak, which is very rare, we have taken the higher of the two peaks. When we define a situation as being characterized by "no bubble" it is either
} 
the relationship between housing prices and the current account (or trade balance) during the build-up of housing prices. Table 1 shows the peak years for the 19 countries in our sample. ${ }^{12}$

Figure 9 about here

Table 1 about here

For each country, we calculate the real appreciation of the prices of residential real estate. For all countries except China we use housing price index data from the OECD. For China, we use an index of residential real estate prices from the Chinese National Bureau of Statistics. To calculate a measure of the current account balance, or balance of trade, we take the deficit or surplus in 1996 as the starting point, and then accumulate all deviations from that starting point over the subsequent years until the peak of the residential real estate price. We then normalise this accumulated total, dividing by GDP in 2008 .

To calculate our regression lines, we ran weighted regressions using real housing price appreciation as the independent variable and the accumulated current account balance, or the accumulated balance of trade, as the dependent variable. Table 2 reports these regressions. Our sample of 19 countries displays a strong negative relationship ( $\mathrm{p}$-value $<0.001$ ) between housing price appreciation and the current account surplus $(\mathrm{R} 2=0.52)$ and between housing price appreciation and the trade surplus $(\mathrm{R} 2=0.50) .{ }^{12}$

\section{Table 2 about here}

These correlations do not settle the issue of causation (cf Basco 2009). There is, however, some evidence suggesting that causality runs from asset bubbles to current account deficits. For example, Greenspan and Kennedy (2007, 2008), show that the increases in housing prices contributed substantially to the consumption boom via home equity loans and mortgage refinancing cash-outs. In 2005, these liquidity channels generated nearly $\$ 500$ billion in flows to households.

because prices have continued to rise (Switzerland) or because prices have been falling (Germany and Japan).

${ }^{12}$ For countries that did not experience a housing bubble and hence have no peak year we use data until 2008, which is the last year for which data is available.

${ }^{12}$ Only Ireland fails to fit our balance of trade regression line (though Ireland is not an outlier in the current account regression. For most countries, the current account balance and the balance of trade are very close in value. This congruence can break down for countries that have large net foreign asset imbalances. 


\section{Two Open Questions}

There are many open questions that we have failed to address, but two stand out in our minds. First, our model takes the existence of the asset bubbles as given and does not explain their origins. This is a critical research question that others have started to address (See e.g. Akerlof and Shiller 2009; Basco 2009; CFG 2008a,b; Caballero and Krishnamurthy, 2006). We anticipate a generation of debate about the origins and even the existence of these bubbles.

Second, our model does not explain why global interest rates fell between 2000 and 2003, and thereafter stayed at a relatively low level. For example, Figure 10 plots the interest rate for 10-year Treasury Inflation Protected Securities (TIPS). ${ }^{12}$ According to the savings glut hypothesis, the low interest rates resulted from a savings boom. However, as we have shown above, there was no global boom in savings/investment. Indeed, during the period that interest rates were falling (2000-2003), the global savings/investment rate was falling (see Figure 6). We now quickly summarize five alternative reasons that interest rates fell from 2000-2003 and remained low thereafter. ${ }^{12}$

First, there are was a substantial asset reallocation from equities to fixed income instruments during and after the bursting of the tech bubble (see Caballero and Krishnamurthy, 2008 for a theoretical treatment of the flight to quality). This trend was enhanced by the advent of monetary authorities with a preference for holding large quantities of reserves invested in U.S. Treasuries (e.g., the People's Bank of China). Second, monetary policy was highly expansionary during and after the 2001 recession. In just 2.5 years, the federal funds rate was lowered from $6.5 \%$ to $1 \%$. However, monetary policy does not explain why the real interest rate stayed low after this expansionary policy was scaled back starting in 2004 (see Ahmed et al., 2002, for a discussion about the role of monetary policy during this period). Third, global asset scarcity caused by the Asian Financial Crises of 1997-1998 contributed to a fall in U.S. interest rates (CFG, 2008a, b; Caballero and Krish-

\footnotetext{
${ }^{12}$ The markets for inflation-indexed bonds suffer from some idiosyncrasies that make interpretation of the data problematic. In the UK inflation-indexed bonds were issued in the early 1980s, but in most other countries these markets are much younger. The US government started issuing Treasury Inflation-Protected Securities (TIPS) in 1997. The markets for inflation-indexed bonds have also had very low volume. The market and its quirks are discussed in Campbell et al. (2009).

${ }^{12}$ Numerous attempts have been made to find a unified model that can explain the behaviour of interest rates over longer time periods. The attempts have generally been successful in explaining a subset of the stylized facts. See e.g. Barro and Sala-i-Martin (1990).
} 
namurthy, 2009). Fourth, until the most recent crisis, there was a growing consensus that the developed economies had become less risky - "the great moderation" (Kim, Chang-Jin, and Charles Nelson, 1999; McConnell, and Perez-Quiros, 2000; Blanchard and Simon, 2001; Kahn et al., 2002; Stock and Watson, 2003; Bernanke, 2004). This perception lowered the risk premium for non-governmental debt. Fifth, the advent of structured finance with the increased demand for AAA-rated assets and the encouragement of the rating agencies, contributed to lower risk-premium for non-governmental fixed income financing (Caballero, 2009; Mendoza and Terrones, 2008).

Figure 10 about here

There are many reasons that interest rates declined from 2000-2003 and then failed to return to their old high levels. A global savings glut does not appear to us to be one of those reasons. Interest rates fell at the same time that the global savings/investment rate also fell. The unprecedented trade and current account imbalances appear to us to be well-explained as a response to country-specific asset bubbles, particularly the housing bubbles (but also the equity market bubbles). We have shown that country-level appreciation in residential real estate alone explains half of the variance in current account deficits during this period. Consumers with notionally healthy balance sheets went on a spending boom that started in the late 1990's. Now that the bubbles have burst, it is clear that those households

spent beyond their means. We anticipate that those international imbalances will eventually disappear as households in the bubble economies gradually scale back their lifestyles to match their much-reduced wealth.

\section{References}

Ahmed, S., Levin, A., and Wilson, B.A. (2002). 'Recent U.S. macroeconomic stability: Good Policies, good Practices, or good Luck?', Board of Governors of the Federal Reserve System, International Finance Discussion Paper 2002-730 (July).

Aizenman, J. and Jinjarak, Y. (2008). 'Current Account Patterns and National Real Estate Markets.' NBER Working Paper No. 13921.

Akerlof, G. A and Shiller, R.J. (2009). Animal Spirits. Princeton University Press, Princeton. 
Barro, R.J. and Sala-i-Martin, X. (1990). 'World real interest rates', NBER Macroeconomics Annual, vol. 5, pp. 15-61.

Basco, Sergi (2009) "Globalization and Financial Development: A Model of the Dot-Com and Housing Bubble," mimeo MIT.

Beaudry, P. and Portier, F. (2007). 'When can changes in expectations cause business cycle fluctuations in neo-classical settings?' Journal of Economic Theory, vol. 135(1), pp. 458-477.

Bernanke, B.S. (2004). 'The great moderation: Remarks by Governor Ben S. Bernanke at the meetings of the Eastern Economic Association, Washington, DC.', The Federal Reserve Board of Governors.

Bernanke, B. S. (2005). 'The global savings glut and the U.S. current account deficit: Remarks by Governor Ben S. Bernanke at the Homer Jones Lecture, St. Louis, Missouri', The Federal Reserve Board of Governors.

Blanchard, O., and Simon, J. (2001). 'The long and large decline in U.S. output volatility', Brookings Papers on Economic Activity, vol. 1, pp. 135-64.

Caballero, R. J.(2009). 'A global perspective on the great financial insurance run: causes, consequences, and solutions', MIT mimeo, January 20 .

Caballero, R. J., Farhi, E. and Gourinchas, P-O.,( 2008a). 'Financial crash, commodity Prices, and global imbalances', Brookings Papers on Economic Activity, Fall, pp 1-55.

Caballero, R. J., Farhi, E. and Gourinchas, P-O. (2008b). 'An equilibrium model of 'global imbalances' and low interest rates', American Economic Review, vol. 98(1), pp. 358-393.

Caballero, R. J. and Krishnamurthy, A.( 2009). 'Global imbalances and financial fragility', American Economic Review, vol. 99(2), pp. 584588.

Caballero, R. J. and Krishnamurthy, A. (2008). 'Collective risk management in a flight to quality episode', Journal of Finance, vol. 63(5)pp. 2195-2230. 
Caballero, R. J. and Krishnamurthy, A. (2006). 'Bubbles and capital flow volatility: causes and risk management', Journal of Monetary Economics, vol. 53(1), pp. 35-53.

Campbell, J.Y, Schiller, R.J. and Viceira, L.M. (2009). 'Understanding inflation-indexed bond markets"' NBER Working Paper 15014.

Christiano, L., Ilut, C., Motto, R. and Rostagno, M. (2007). 'Monetary policy and stock market boom-bust cycles. North Western University, mimeo.

Glaeser, E.L., Gyourko, J. and Saiz, A. (2008). Housing Supply and Housing Bubbles. Mimeo, Harvard University. Gourinchas, P-O. and Rey, H. (2007) 'International Financial Adjustment', Journal of Political Economy, vol 115(4), pp. 665-703.

Greenspan, A. and Kennedy, J. (2007). 'Sources and uses of equity extracted from homes' Finance and Economic Discussion Series 2007-20, Washington, DC, Board of Governors of the Federal Reserve System.

Greenspan, A. and Kennedy, J. (2008). 'Sources and uses of equity extracted from homes', Oxford Review of Economic Policy, vol. 24(1), pp. $120-144$.

Hausmann, R. and Sturzenegger, F. (2005) U.S. and global imbalances: Can dark matter prevent a big bang? Working Paper, Kennedy School of Government.

Kahn, J., McConnell, M., and Perez-Quiros, G. (2002). 'On the causes of the increased stability of the U.S. economy', Economic Policy Review,vol. 8, pp. 183-202.

McGrattan, E.R. and Prescott, E.C. (2009). Unmeasured investment and the puzzling U.S. boom in the 1990s. Research Department Staff Report 369, Federal Reserve Bank of Minneapolis.

Kim, C. and Nelson, C. (1999). 'Has the U.S. economy become more stable? A bayesian approach based on a Markov-switching model of the business cycle', Review of Economics and Statistics, Vol. 81, pp. 608-616.

Kraay, A. and Ventura, J. (2007) "The Dot-Com Bubble, the Bush Deficits, and the US Current Accounts" in Clarida (eds.), G1 Current Account 
Imbalances: Sustainability and Adjustment, University of Chicago Press.

McConnell, M., and Perez-Quiros. G. (2000). 'Output fluctuations in the United States: What has changed since the early 1980s?', American Economic Review, vol. 90, pp. 1464-1476.

Mendoza, E. G. and Terrones, M.. (2008). 'An anatomy of credit booms: Evidence from macro aggregates and micro aata', NBER Working Paper 14049.

Shiller, R.J. (2005). Irrational Exuberance. Second Edition. Princton: Princton University Press.

Stock, J., and Watson, M. (2003). "'Has the business cycle changed? Evidence and explanations', prepared for the Federal Reserve Bank of Kansas City symposium, "Monetary Policy and Uncertainty," Jackson Hole, Wyoming, August 28-30.

Ventura, J. "A Portfolio View of the US Current Account Deficit", Brookings Papers on Economic Activity, 1, 2001, 241-253. 
Figure 1: Current Account Balance as Percentage of GDP, US, China, OECD and BRIC

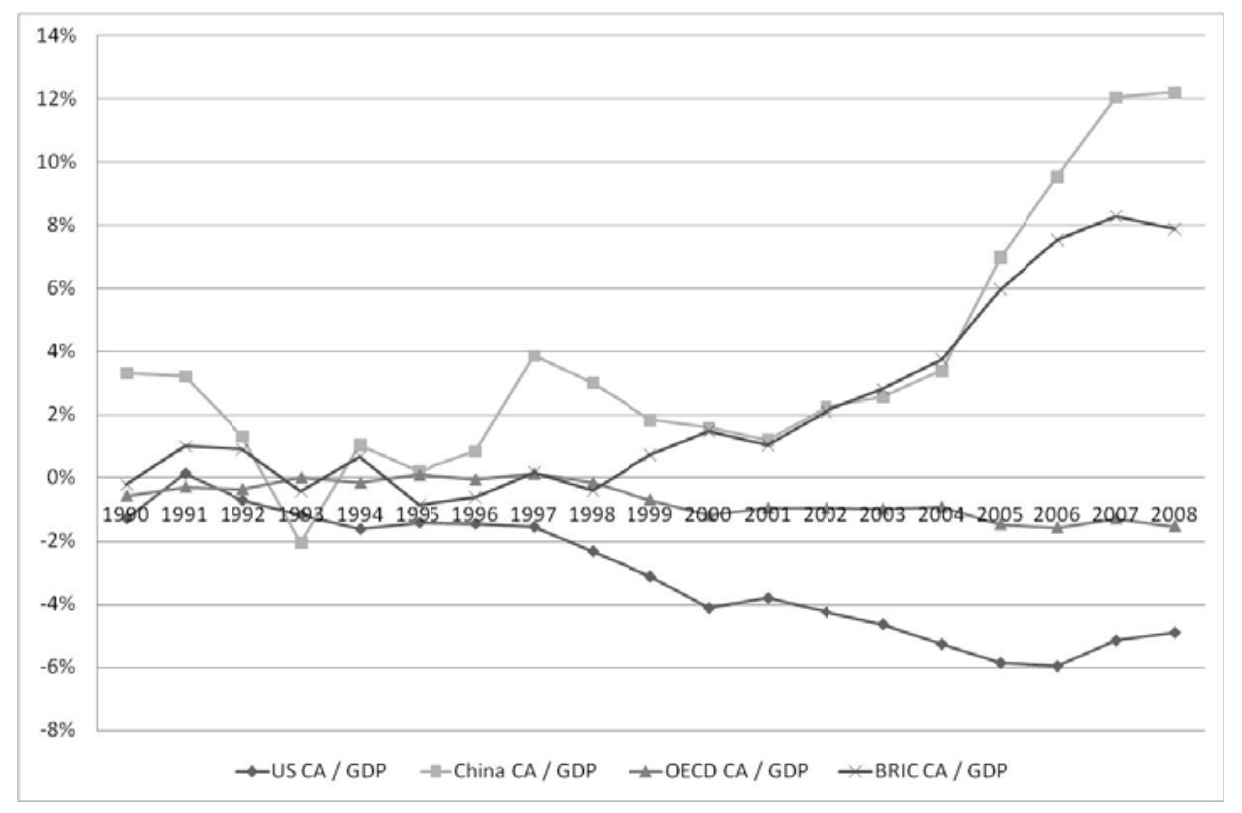

Source: Economist Intelligence Unit, OECD, BEA-NIPA, State Administration of Foreign Exchange (China)

Figure 2: Housing Price Appreciation vs Current Account Accumulation, 1996 - peak of housing market

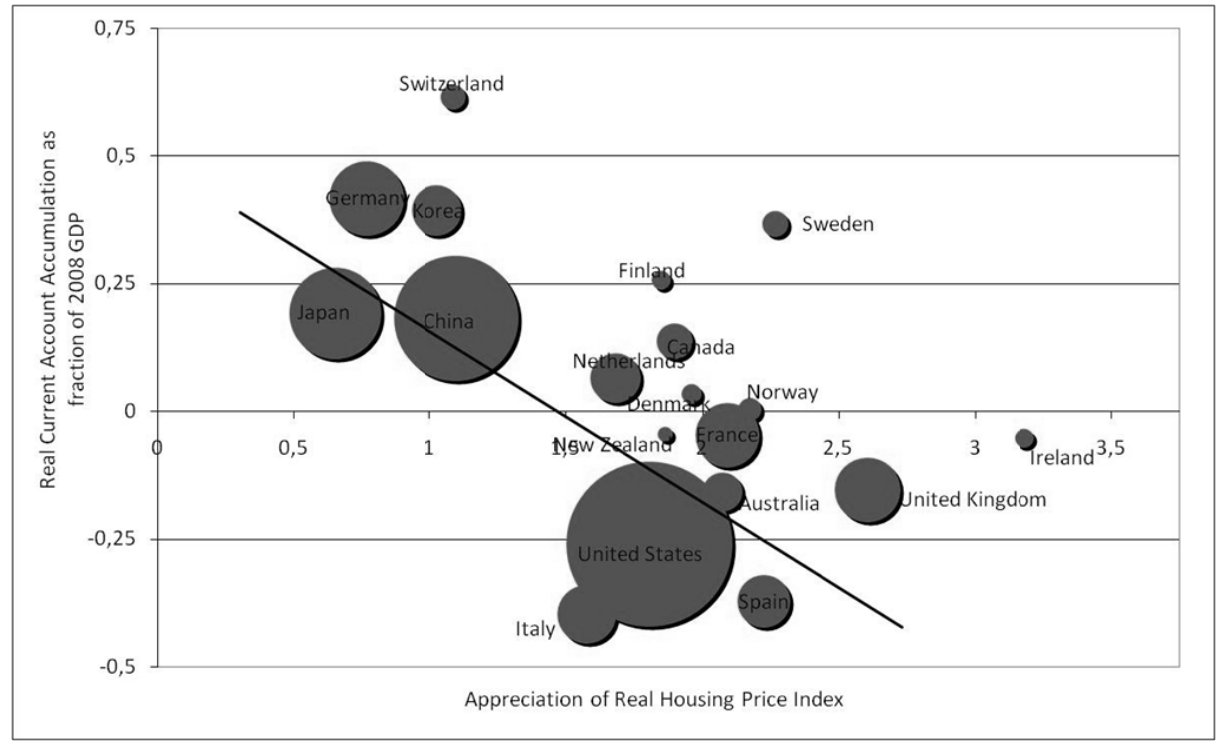

Source: Economist Intelligence Unit, $O E C D, I M F$, State Administration of Foreign Exchange (China), De Nederlandsche Bank, BEA. The area of each circle is proportional to 2008 GDP. The calculations used to generate this figure are explained in section III.B and the peak quarters are reported in Table 1. 
Figure 3: US Current Account Deficit as Percentage of GDP, 1929-2008

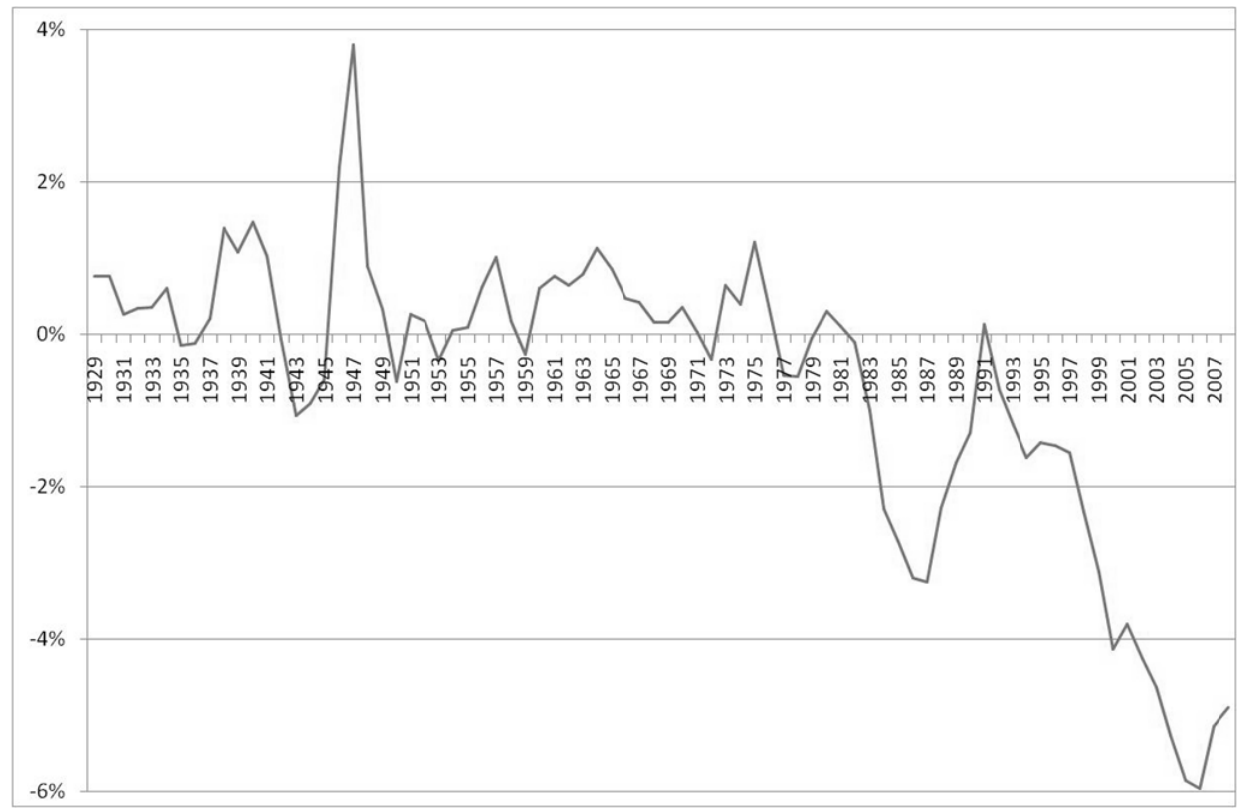

Source: BEA-NIPA

Figure 4: US Investment Rate (I/GDP), 1929-2008

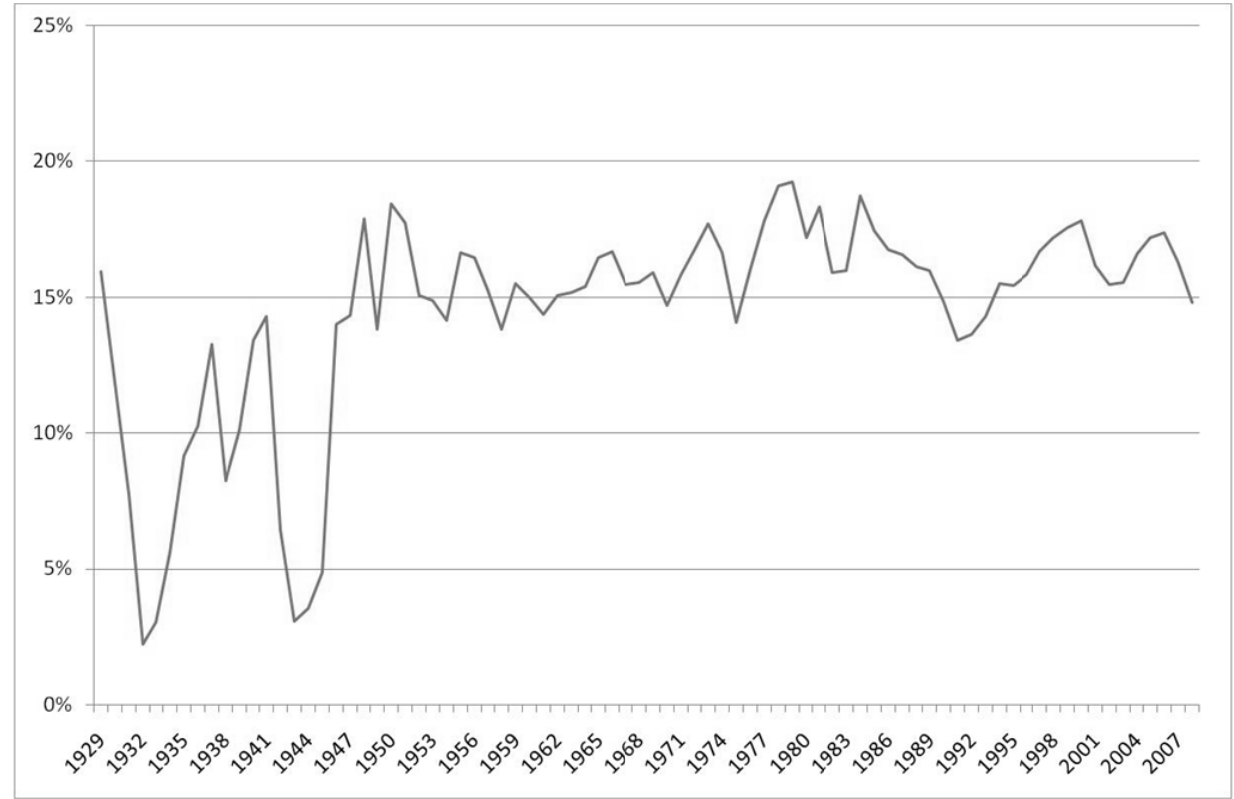

Source: BEA-NIPA 
Figure 5: US Residential Investment, Percentage of GDP, 1929-2008

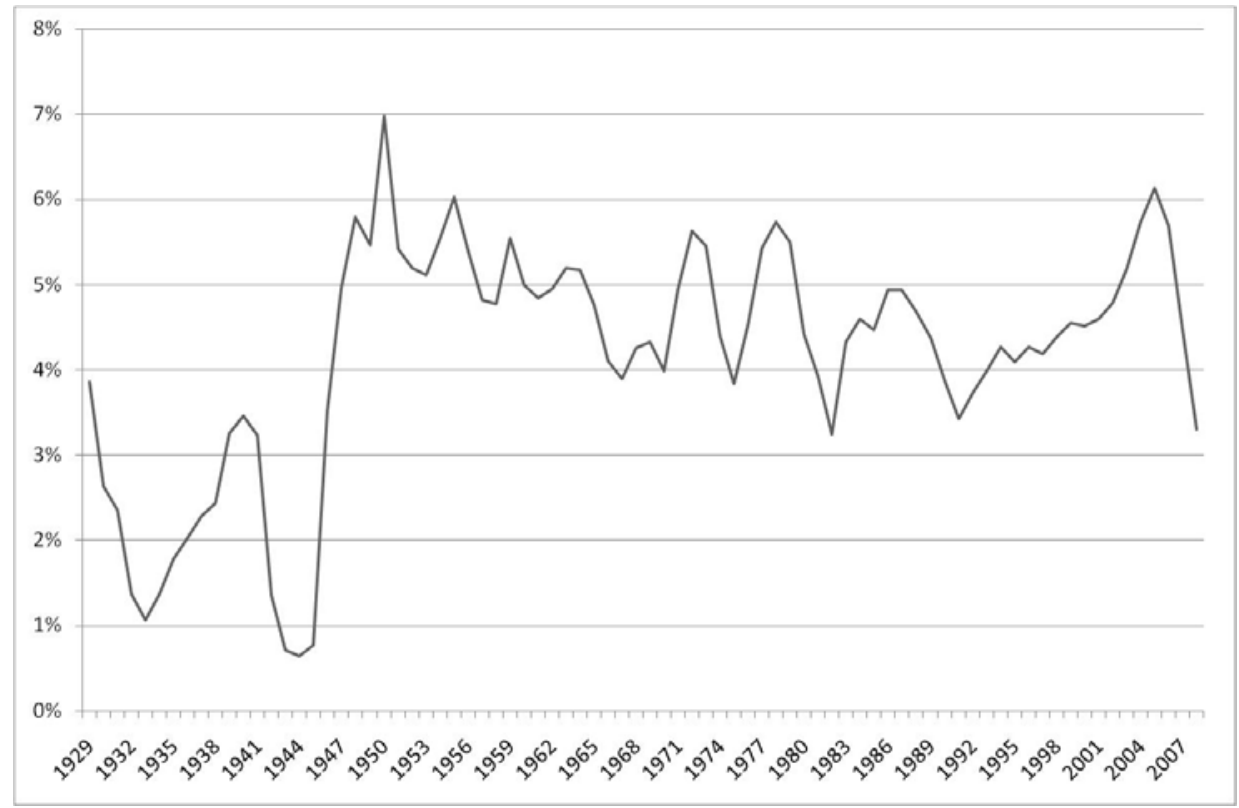

Source: BEA-NIPA

Figure 6: Global Investment Rate and Savings Rate, 1992-2008

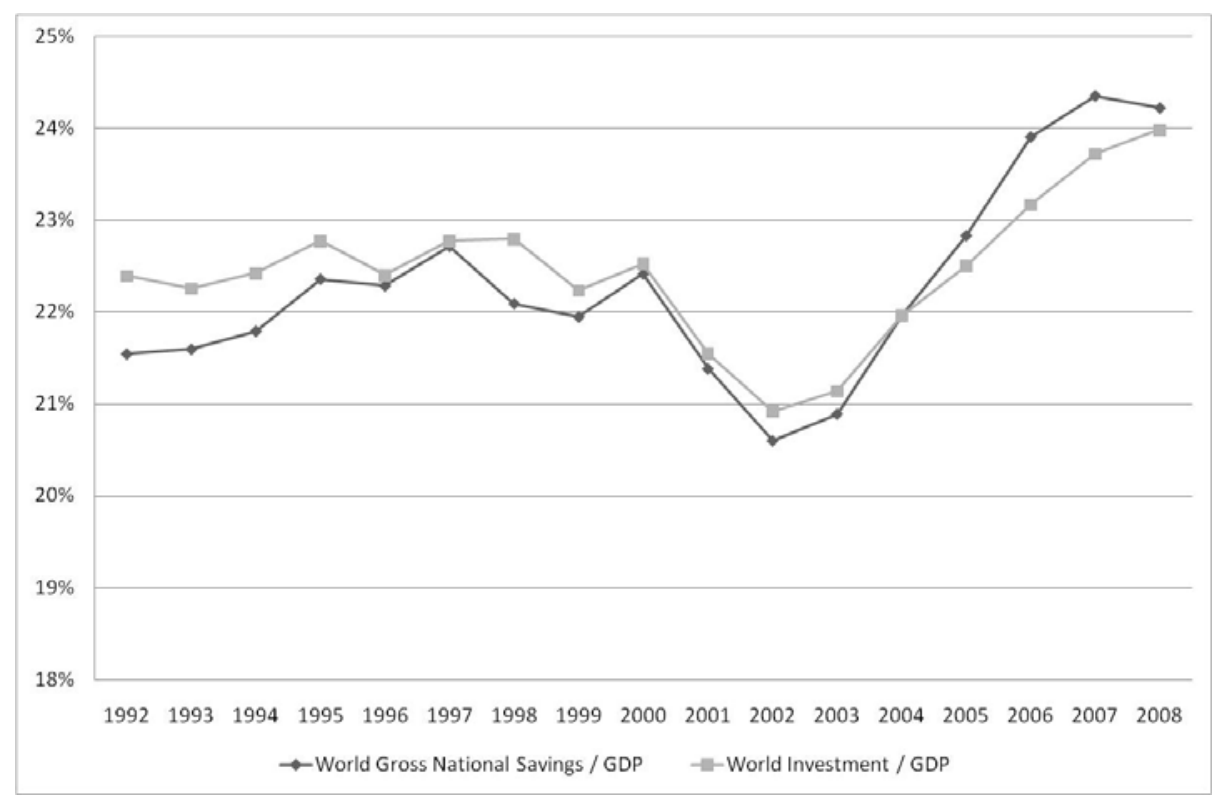

Source: IMF. Data for 2007 and 2008 are preliminary estimates. 
Figure 7: Predicted change in investment rate and real investment rate data (US), percent

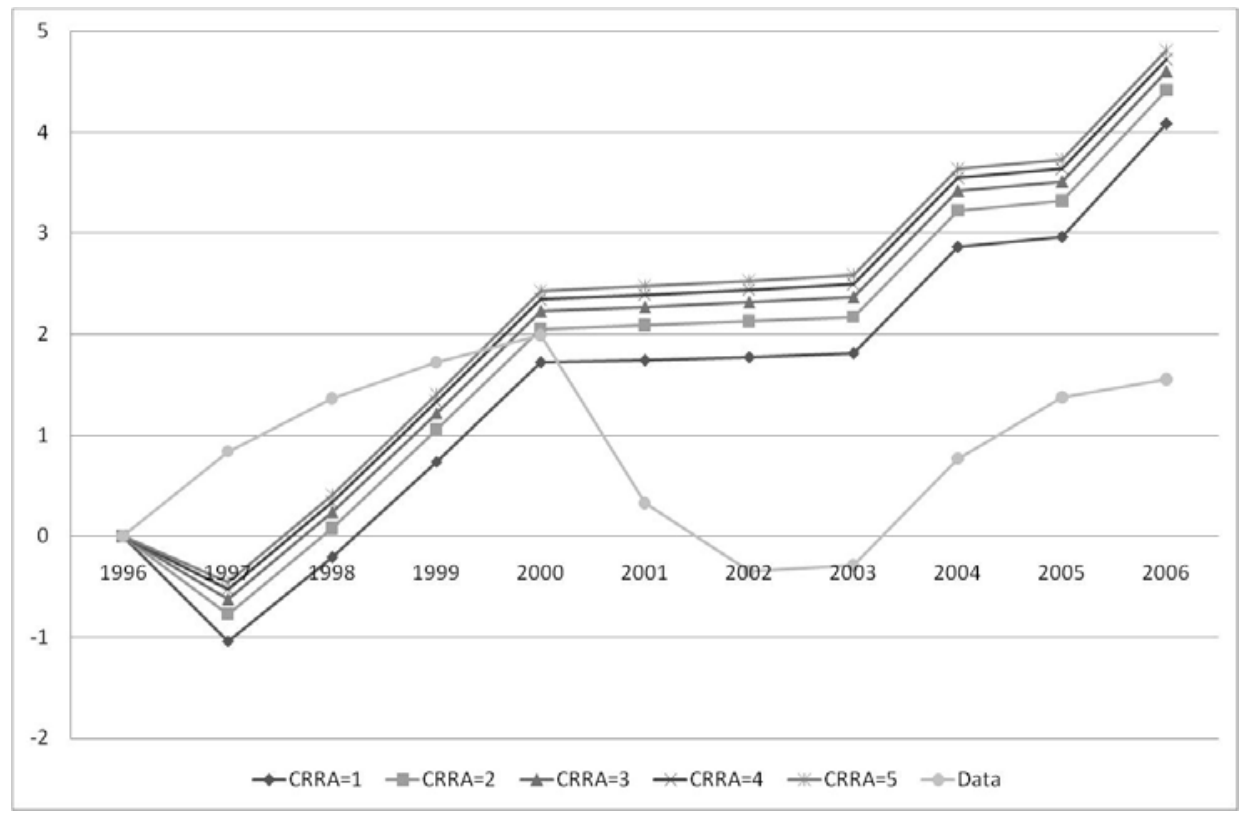

Source: BEA-NIPA, Own calculations

Figure 8: Household net worth divided by GDP, US

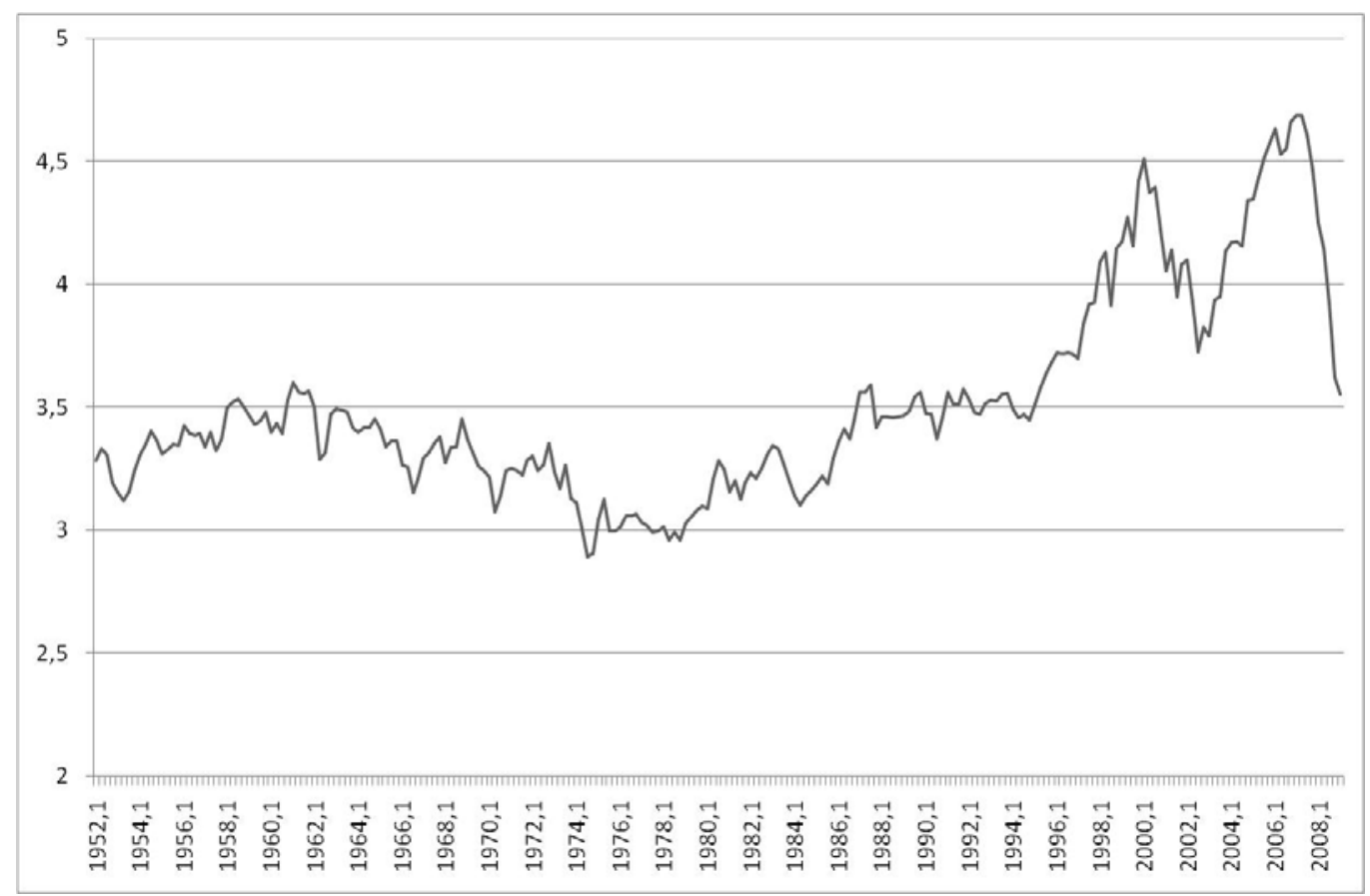

Source: Federal Reserve Board, BEA, and authors calculations 
Figure 9: Housing Price Appreciation vs Balance of Trade Accumulation, 1996 - peak of housing market

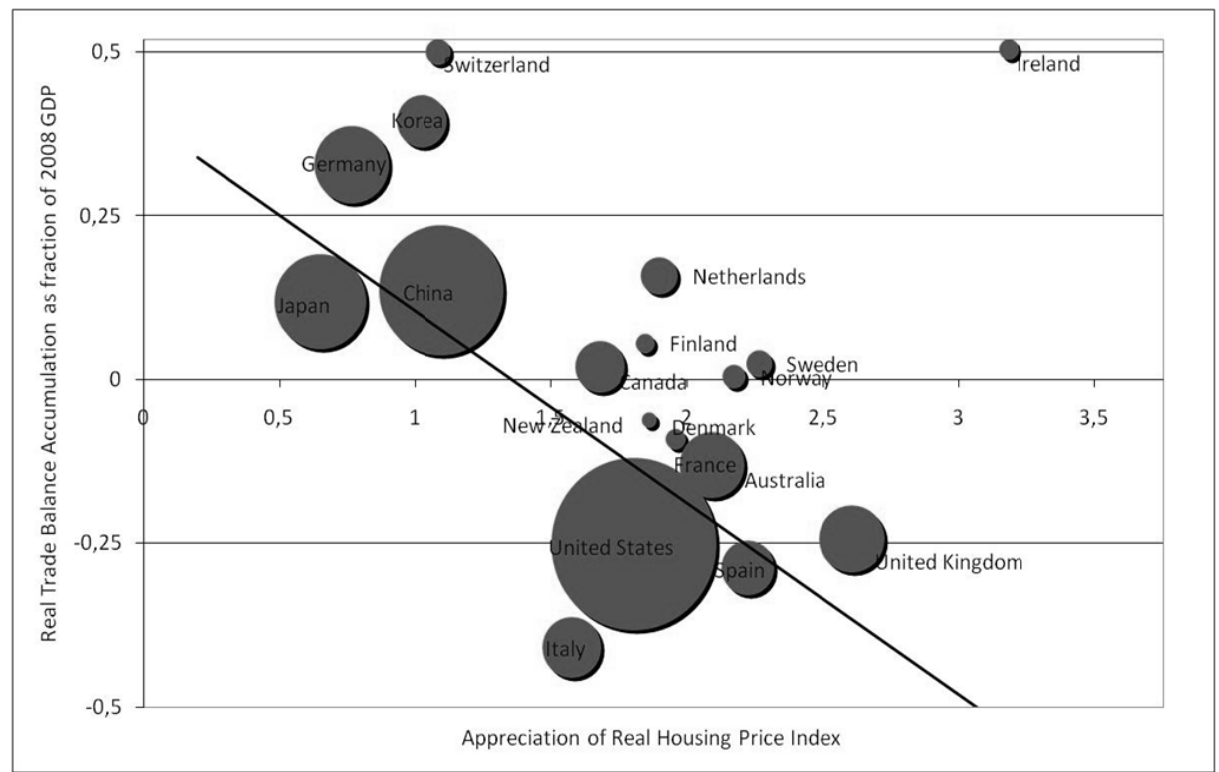

Source: Economist Intelligence Unit, OECD, IMF, State Administration of Foreign Exchange (China), De Nederlandsche Bank, BEA. The area of each circle is proportional to 2008 GDP. See text for explanation of calculations and see Table 1 for peak quarters

Figure 10: US Real Yield

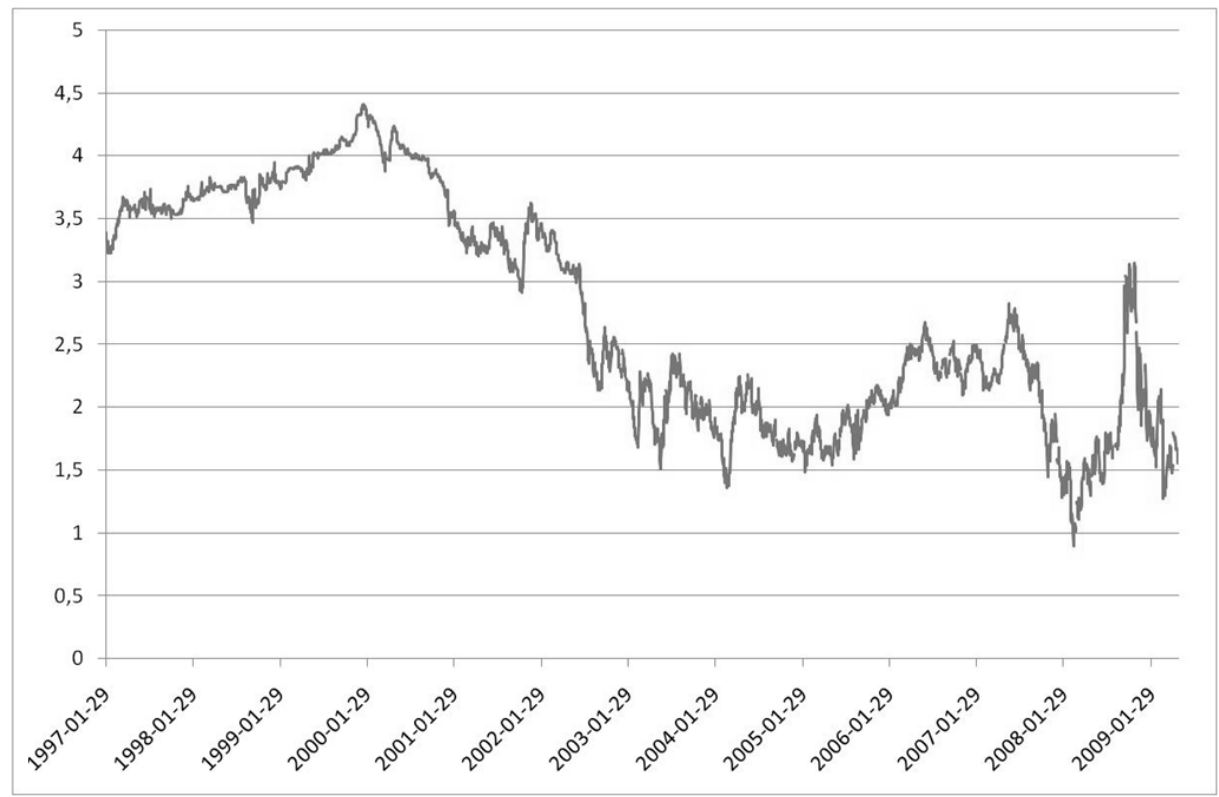

Source: Federal Reserve Board 
Table 1: Peak Date (Year: Quarter) for Housing Price Bubble

$\begin{array}{lr}\text { Country } & \text { Peak Date } \\ \text { Australia } & 2008: 1 \\ \text { Canada } & 2007: 4 \\ \text { China } & 2008: 1 \\ \text { Denmark } & 2007: 1 \\ \text { Finland } & 2007: 4 \\ \text { France } & 2007: 4 \\ \text { Germany } & \text { no bubble } \\ \text { Ireland } & 2006: 3 \\ \text { Italy } & 2007: 4 \\ \text { Japan } & \text { no bubble } \\ \text { Korea } & 2007: 1 \\ \text { Netherlands } & 2008: 1 \\ \text { New Zealand } & 2007: 3 \\ \text { Norway } & 2007: 3 \\ \text { Spain } & 2007: 3 \\ \text { Sweden } & 2007: 4 \\ \text { Switzerland } & \text { no bubble } \\ \text { United Kingdom } & 2007: 4 \\ \text { United States } & 2006: 4\end{array}$

Source: Economist Intelligence Unit, National Bureau of Statistics of China, OECD, and authors' calculations as described in text.

Table 2: Results from weighted regressions

\begin{abstract}
Dependent variable
CA accumulation, 1996-peak

BoT accumulation, 1996-peak (incl. Ireland)

BoT accumulation, 1996-peak (ex. Ireland)
\end{abstract}

$\begin{array}{rrr}\text { Coefficient estimate } & \text { p-value } & \text { R-square } \\ -0.33 & 0.000 & 0.5211 \\ -0.29 & 0.001 & 0.5015 \\ -0.32 & 0.000 & 0.5882\end{array}$

Source: OECD, National Bureau of Statistics of China, Economist Intelligence Unit, Own calculations 